\title{
Effect of estrogen receptor gene ESR1 polymorphism on development of premenstrual syndrome
}

\author{
L.V. Pakharenko \\ SHEE «Ivano-Frankivsk National Medical University»
}

Georgian medical news. No 10( 235) 2014, p. 37-40.

To identify risks of development of any disease is a priority of modern medicine. The aim of this study was to investigate the frequency of polymorphic variants of A-351G gene estrogen receptor ESR1 in patients with various forms of PMS. Molecular genetic analysis of ESR1 gene polymorphism in 50 women with PMS (25 women of them had edematous form of disease, 25 - neuropsychical, 25 - mild, 25 - severe form) was carried out. 25 women without diagnosis of PMS were examined as controls.

The study A-351G polymorphism estrogen gene ESR1 showed no statistically significant differences in the frequency of distribution of genotypes and alleles between women with PMS and without this pathology. However, the frequency of GG genotype in women with severe PMS was significantly higher in 8.0 times compared with healthy women $\left(\chi^{2}=4.87, \mathrm{p}=0.03\right)$ and in women with edematous form of PMS - in 7.0 times $\left(\chi^{2}=3.72, p=0.05\right)$. Thus, a polymorphic variant of A-351G gene ESR1 estrogen can be considered as a marker of PMS. Pathological variant GG genotype was significantly associated with the presence of edematous and severe forms of the disease.

Key words: premenstrual syndrome, estrogen receptor gene ESR1, polymorphism.

\section{Влияние полиморфизма гена рецептора эстрогена ESR1 на реализацию развития предменструального синдрома \\ Л.В. Пахаренко}

Определение рисков развития болезни является приоритетным направлением современной медицины. Целью данного исследования было изучение частоты полиморфных вариантов A-351G гена рецептора эстрогена ESR1 у больных различными формами предменструального синдрома (ПМС). Проведен молекулярно-генетический анализ полиморфизма гена ESR1 у 50 женщин с ПМС, из них у 25 женщин с отечной и 25 - с нейропсихической формами, 25 женщин имели легкую, 25 - тяжелую форму заболевания. Обследованы также 25 женщин без диагноза ПМС.

В результате исследования A-351G полиморфного локуса гена эстрогена ESR1 статистически значимых различий в распределении частот генотипов и аллелей между женщинами с ПМС и без этой патологии не выявлено. Однако частота генотипа GG y женщин с тяжелой формой ПМС была достоверно выше - в 8,0 раза в сравнении со здоровыми женщинами $\left(\chi^{2}=4,87 ; \mathrm{p}=0,03\right)$, у женщин с отечной формой ПМС - в 7,0 раза $\left(\chi^{2}=3,72 ; \mathrm{p}=0,05\right)$. Таким образом, полиморфный вариант A-351G гена эстрогена ESR 1 можно рассматривать в качестве маркера развития ПМС. Патологический вариант GG генотипа достоверно ассоциируется с наличием отечной и тяжелой форм заболевания.

Ключевые слова: предменструальный синдром, ген рецептора эстрогена ESR1, полиморфизм.

\section{Вплив поліморфізму гена рецептора естрогену ESR1 на реалізацію розвитку передменструального синдрому \\ Л.В. Пахаренко}

Визначення ризиків розвитку хвороби є пріоритетним напрямком сучасної медицини. Метою даного дослідження було вивчення частоти поліморфних варіантів A-351G гена рецептора естрогену ESR1 у хворих з різними формами передменструального синдрому (ПМС). Проведено молекулярно-генетичний аналіз поліморфізму гена ESR1 у 50 жінок з ПМС, 3 них у 25 жінок 3 набряклою і у 25 - 3 нейропсихічною формами, у 25 жінок діагностовано легку, у 25 - тяжку форму захворювання. Обстежено також 25 жінок без діагнозу ПМС. У результаті дослідження A-351G поліморфного локусу гена естрогену ESR1 статистично значущих відмінностей у розподілі частот генотипів і алелей між жінками з ПМС і без цієї патології не виявлено. Проте частота генотипу GG у жінок з тяжкою формою ПМС була достовірно вище - у 8,0 разу порівняно зі здоровими жінками $\left(\chi^{2}=4,87 ; \mathrm{p}=0,03\right)$, а у жінок з набряклою формою ПМС - у 7,0 разу $\left(\chi^{2}=3,72\right.$; $\mathrm{p}=0,05)$. Отже, поліморфний варіант A-351G гена естрогену ESR1 можна розглядати в якості маркера розвитку ПМС. Патологічний варіант GG генотипу достовірно асоціюється з наявністю набряку і тяжкої форм захворювання.

Ключові слова: передменструальний синдром, ген рецептора естрогену ESR1, поліморфізм.

$\mathrm{P}$ remenstrual syndrome (PMS) - is a functional disorder of the central nervous system under the influence of adverse exogenous or endogenous factors on the background of the acquired or congenital lability of hypothalamic-pituitary-ovarian system [5]. Symptoms of psychological, endocrine, vegetative, metabolic nature arise in luteal phase of menstrual cycle and significantly disturb usual life of a woman.

Hormonalaspects of PMS are convincing. One of the first theories of development of this disease is the theory hyperestrogenemy. Estrogens exert their effects on cells by binding with $\alpha$ or $\beta$ receptors. These receptors are encoded by genes ESR1 and ESR2. Expression of these genes is located not only female in genital tissues, but also in cells of the prostate, heart, lungs, kidneys, etc. [4]. There are only some reports about of ESR gene polymorphism in the development of gynecological pathology. This is possibly due to the relatively recent tendency of research and development of new technologies in medicine. There is a close relationship of $\mathrm{A} / \mathrm{G}$ polymorphism of ESR1 with endometriosis and infertility on its background and ESR2 gene polymorphism is not associated with development of this disease [11]. In women with infertility and low response to ovarian stimulation genotype AG gene ESR1 was found most frequently [3]. ESR1 gene polymorphism may be associated with the development of dysmenorrhea [12], migraine [7,9], the regulation of behavior and mood of women $[8,10]$.

The objective: investigate the frequency of polymorphic variants of A-351G gene estrogen receptor ESR1 in patients with various forms of PMS. 


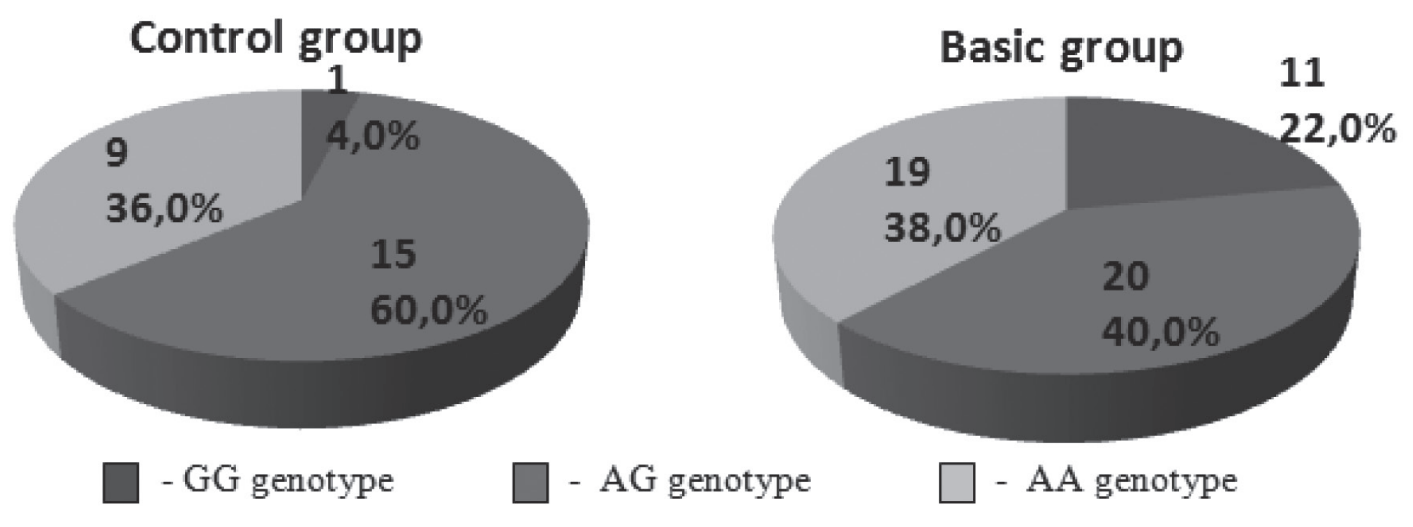

The frequency of polymorphic variants of A-351G estrogen receptor gene ESR1 among examined women

\section{MATERIAL AND METHODS}

The study included 200 women with premenstrual syndrome, which formed basic group. The control group consisted of 50 healthy women without diagnosis of PMS. Verification of diagnosis and severity of disease (mild and severe) was performed according to Order of Ministry of Health of Ukraine № 676 from 31.12.2004 [5]. Diagnosis of PMS was exhibited by presence of cyclical manifestations of the disease in luteal phase of menstrual cycle on the basis of history-taking and results of patient's self-observation diary for 2-3 menstrual cycles (R. Moos Menstrual Distress Questionnaire). Form of PMS (edematous, neuropsychical, cephalgic, crisis) was determined in accordance with the classification of V.P. Smetnik's [6]. Clinical examination was carried out on the basis of Ivano-Frankivsk clinical maternity hospital (Ivano-Frankivsk, Ukraine).

The criteria for inclusion of patients in research were: the reproductive age (18-44 years), regular menstrual cycles, presence of PMS, written consent of the patient. Exclusion criteria: women who had at the time of the study pregnancy or lactation, disorders of menstrual cycle, focal lesions of breast, dysfunctional uterine bleeding of unknown etiology, acute inflammation of pelvic organs, tumors of uterus and ovaries of unknown etiology, endometrial hyperplasia, genital endometriosis, severe somatic pathology in the history, organic pathology of the central nervous system, mental illness, hormonal tumors, diabetes, adrenal diseases, malignant tumors in the present or in anamnesis, premenstrual dysphoric disorder, women who took psychotropic medications or hormonal therapy within the last 3 months.

The average age of women in control and basic groups was not statistically different and was respectively $28.82 \pm 0.76$ and $30.13 \pm 0.36$ years $(\mathrm{p}=0.08)$. Age of menarche corresponded in two groups $-12.94 \pm 0.13$ and $12.86 \pm 0.06$ years and had no differences depending on the form of PMS $(p>0.05)$. We found

The frequency of A-351G polymorphism of the estrogen receptor gene ESR1 in women with different forms of PMS

\begin{tabular}{|c|c|c|c|c|c|c|c|}
\hline \multirow{2}{*}{ Groups } & \multirow{2}{*}{$\mathbf{n}$} & \multicolumn{2}{|c|}{ GG genotype } & \multicolumn{2}{c|}{ AG genotype } & \multicolumn{2}{c|}{ AA genotype } \\
\cline { 5 - 9 } & & Abs. & $\%$ & Abs. & $\%$ & Abs. & \% \\
\hline Control group & 25 & 1 & 4.0 & 15 & 60.0 & 9 & 36.0 \\
\hline Edematous form of PMS & 25 & 7 & 28.0 & 9 & 36.0 & 9 & 36.0 \\
\hline Neuropsychical form of PMS & 25 & 4 & 16.0 & 11 & 44.0 & 10 & 40.0 \\
\hline Mild form of PMS & 25 & 3 & 12.0 & 14 & 56.0 & 8 & 32.0 \\
\hline Severe form of PMS & 25 & 8 & 32.0 & 6 & 24.0 & 11 & 44.0 \\
\hline Basic group, total & 50 & 11 & 22.0 & 20 & 40.0 & 19 & 38.0 \\
\hline
\end{tabular}

The frequency of genotypes of estrogen receptor gene ESR1 among examined women, depending on form of PMS compared with control group

\begin{tabular}{|c|c|c|c|c|c|c|c|c|c|c|}
\hline \multirow{2}{*}{ Groups } & \multirow{2}{*}{$\mathbf{n}$} & \multicolumn{3}{|c|}{ GG genotype } & \multicolumn{3}{|c|}{ AG genotype } & \multicolumn{3}{|c|}{ AA genotype } \\
\hline & & $\%$ & $\chi^{2}$ & $p$ & $\%$ & $\chi^{2}$ & $p$ & $\%$ & $\chi^{2}$ & p \\
\hline Control group & 25 & 4.0 & & & 60.0 & & & 36.0 & & \\
\hline Edematous form of PMS & 25 & 28.0 & 3.72 & 0.05 & 36.0 & 2.00 & 0.16 & 36.0 & 0.09 & 0.77 \\
\hline Neuropsychical form of PMS & 25 & 16.0 & 0.89 & 0.35 & 44.0 & 0.72 & 0.39 & 40.0 & 0.00 & 1.00 \\
\hline Mild form of PMS & 25 & 12.0 & 0.27 & 0.60 & 56.0 & 0.00 & 1.00 & 32.0 & 0.00 & 1.00 \\
\hline Severe form of PMS & 25 & 32.0 & 4.87 & 0.03 & 24.0 & 5.25 & 0.01 & 44.0 & 0.08 & 0.77 \\
\hline Basic group, total & 50 & 22.0 & 2.79 & 0.09 & 40.0 & 1.93 & 0.16 & 38.0 & 0.01 & 0.93 \\
\hline
\end{tabular}

Note: $p$ - probability of the difference of indicator relative to control group. 
Genotypes A-351G polymorphism of estrogen receptor gene ESR1 as risk markers of PMS

\begin{tabular}{|c|c|c|c|c|}
\hline Forms of PMS & Mark & GG genotype & AG genotype & AA genotype \\
\hline \multirow{3}{*}{ Edematous form of PMS } & OR & 9.33 & 0.37 & 1.00 \\
\hline & $\mathrm{Cl}$ & $1.05-82.78$ & $0.12-1.18$ & $0.31-3.17$ \\
\hline & $\mathrm{p}$ & 0.04 & 0.09 & 1.00 \\
\hline \multirow{3}{*}{$\begin{array}{l}\text { Neuropsychical form of } \\
\text { PMS }\end{array}$} & OR & 4.57 & 0.52 & 1.18 \\
\hline & $\mathrm{Cl}$ & $0.47-44.17$ & $0.17-1.61$ & $0.38-3.72$ \\
\hline & $p$ & 0.19 & 0.26 & 0.77 \\
\hline \multirow{3}{*}{ Mild form of PMS } & OR & 3.27 & 0.85 & 0.84 \\
\hline & $\mathrm{Cl}$ & $0.32-33.84$ & $0.27-2.61$ & $0.26-2.70$ \\
\hline & $\mathrm{p}$ & 0.32 & 0.77 & 0.77 \\
\hline \multirow{3}{*}{ Severe form of PMS } & OR & 11.29 & 0.21 & 1.39 \\
\hline & $\mathrm{Cl}$ & $1.29-98.89$ & $0.06-0.71$ & $0.45-4.35$ \\
\hline & $\mathrm{p}$ & 0.03 & 0.01 & 0.56 \\
\hline \multirow{3}{*}{ Basic group, total } & OR & 6.77 & 0.44 & 1.09 \\
\hline & $\mathrm{Cl}$ & $0.82-55.79$ & $0.17-1.18$ & $0.40-2.95$ \\
\hline & $p$ & 0.07 & 0.10 & 0.87 \\
\hline
\end{tabular}

that the average age of onset of this disease was $23.79 \pm 0.29$ years. $45(90.0 \%)$ women in control group had a history of gynecological diseases, 31 (62.0\%) women of them had two or more diseases. In basic group we noticed a similar trend, the figures were, respectively, 198 (99.0\%) and 136 women (68.0\%). A significant percentage of gynecological pathology occupied chronic inflammation of uterine appendages $(68.0 \%$ and $59.0 \%$, respectively), as well as inflammation of the lower genital tract $(44.0 \%$ and $54.5 \%) .26 .0 \%$ of women in both groups had menstrual disorders in anamnesis. Only 22 women $(44.0 \%)$ in control group had a history of pregnancy, which was 1.59 times lower than in basic group (140 women $-70.0 \%$; $\chi^{2}=10.74, \mathrm{p}=0.001, \mathrm{OR}=2.96,95 \%$ CI 1,57-5,60, $\left.\mathrm{p}<0.001\right)$. Noteworthy is the fact that women with PMS had more labors - $64.5 \%$ versus $38.0 \%$ in control group $\left(\chi^{2}=10.56, p=0.001\right.$, $\mathrm{OR}=2.96,95 \%$ CI $1.56-5.62, \mathrm{p}<0.001$ ).

Given that the most common forms of PMS are edematous and neuropsychical, we performed molecular genetic analysis of ESR1 gene polymorphism in 50 women of basic group, 25 of them had edematous form of disease, 25 - neuropsychical, 25 - mild, 25 - severe. Also 25 women of control group were examined.

A-351G polymorphism of the gene ESR1 estrogen was determined in the research laboratory, Department of Medical Genetics, Shupyk National Medical Academy of Postgraduate Education (Kyiv). Material for the study was peripheral blood, which was collected into tubes with EDTA in amount of $2.7 \mathrm{ml}$, then DNA was isolated using a commercial set «DNA-sorb-B» (Institute of Epidemiology of the Ministry of Health of Russian Federation). After the polymerase chain reaction with the reagents of the company Fermentas (Lithuania) in thermocycler «FlexCycler» (Analytik, Jena, Germany) restriction fragment length polymorphism was analyzed. The amplification products of A-351G gene ESR1 fragments were splitted using restriction endonuclease PvuII. Then, electrophoresis of resulting fragments in $2 \%$ agarose gel with the addition of ethidium bromide and visualization by computer system Vitran were performed.

For statistical analysis of the results we used the criterion $\chi^{2}$, odds ratio (OR), confidence interval (CI).

\section{RESULTS AND THEIR DISCUSSION}

We found no statistically significant differences in the distribution of allele and genotype frequencies of A-351G polymorphic estrogen receptor gene ESR1 between women of control and basic groups (see fig. 1). The frequency of heterozygous genotype AG was similar in both groups, but among healthy women met at 1.50 times more than in patients with PMS and reached $60.0 \%$ and $40.0 \%$, respectively $\left(\chi^{2}=1.93\right.$; $\mathrm{p}=0.16, \mathrm{OR}=0.44,95 \%$ CI $0.17-1.18 ; \mathrm{p}=0.10$ ).

In women with edematous, neuropsychical and mild forms of disease AG genotype was predominant (table 1).

However, we found that $24.0 \%$ of women with severe PMS found significantly lower in 2.50 times frequency of AG genotype compared with healthy women $\left(\chi^{2}=5.25, \mathrm{p}=0.02, \mathrm{OR}=0.21,95 \%\right.$ CI 0.06-0.71, $\mathrm{p}=0.01$, table 2 ).

In women of basic group GG genotype was determined at 5.50 times more than of control one (22.0\% and $4.0 \%$, respectively), but the differences did not reach statistical significance $\left(\chi^{2}=2.79\right.$; $\mathrm{p}=0.09, \mathrm{OR}=6.77,95 \%$ CI $0.82-55.79, \mathrm{p}=0.07)$. Mark OR of the distribution of GG genotype in women with PMS compared with healthy women greater than 1 , namely 6.77 , may indicate a possible association of AG polymorphism in the development of the disease (Table 3).

Women with edematous form of PMS had significantly higher in 7.0 times frequency of GG genotype (28.0\%) than in control group $\left(\chi^{2}=3.72 ; p=0.05\right)$. A frequency of $G G$ genotype in women with severe PMS was significantly higher in the 8.0 times compared with healthy women, and accounted for $32.0 \%\left(\chi^{2}=4.87, p=0.03\right)$. The odds ratio of groups with edematous and severe forms of PMS compared with control group is high $(\mathrm{OR}=9.33-11.29, \mathrm{p}=0.03-0.04)$, and points to the link of GG genotype with the occurrence of a certain form of the disease.

Thus, GG genotype may be regarded as a marker for increased risk of PMS, namely, its severe and edematous forms.

The frequency of the homozygous AA genotype was similar in the two groups of patients (38.0\% of women with PMS and $36.0 \%$ of healthy women) and did not differ significantly depending on the clinical form and course of the disease.

$\mathrm{G}$ allele was determined in $31(62.0 \%)$ women with PMS and $16(64.0 \%)$ healthy women, A allele - in $49(98.0 \%)$ and $24(96.0 \%)$ persons, respectively. Distribution of $\mathrm{G}$ allele in women with various forms of PMS was approximately the same: in patients with edematous form it was determined in $16(64.0 \%)$ women, neuropsychical - $15(60.0 \%)$, mild - $17(68.8 \%)$, severe - $14(56.0 \%)$. A allele was found in $18(72.0 \%)$ women with edematous form of PMS, 21 (84.0\%) - neuropsychical, $22(88.0 \%)$ - mild, 17 (68.0\%) - severe. Statistically significant differences between groups were not observed. 
Estrogen receptor gene ESR1 polymorphism as a factor of development of PMS is studied poorly. N.V. Aganezova indicates approximately the same distribution of genotypes A/G gene ESR between women with PMS and without this pathology, which corresponds to the results of our study. The author confirms that for women with PMS and genotype GG are characterized by mood swings, as well as such phenomena as affective lability, tendency to asthenic, hypochondriacal, anancastic features [1]. Therefore, this genotype she considers as «a marker which indirectly predisposes originality emotional and personal characteristics of women with PMS» [2].

\section{CONCLUSION}

A polymorphic variant of A-351G gene estrogen receptor ESR1 can be regarded as a marker for the development of PMS. Pathological variant GG genotype was significantly associated with the presence of edematous and severe forms of the disease.

\section{Сведения об авторе}

Пахаренко Людмила Владимировна - ГВУЗ «Ивано-Франковский национальный медицинский университет», 76018, г. Ивано-Франковск, ул. Галицкая, 2; тел.: (097) 430-69-21. E-mail: ludapak@rambler.ru

\section{REFERENCES}

1. Аганезова Н.В. Роль наследственных и гормональних факторов в развитии предменструального синдрома. Журнал акушерства и женских болезней 2011; LX (Выпуск1): 12-20.

2. Аганезова Н.В., Морозова Е.Б., Чухловин А.Б., Корчагина З.В. Ассоциации проявлений предменструального синдрома в психоэмоциональной сфере с генным полиморфизмом гена рецептора эстрогенов ER-1. Журнал акушерства и женских болезней 2011; LX (Выпуск 2): 14-20.

3. Запорожан В.М., Борис О.М. Зв'язок низького рівня відповіді на стимуляцію овуляції у пацієнток 3 синдромом полікистозних яєчників із функціональним генетичним полімор- фізмом. Медико-соціальні проблеми сім'ї 2011; 3: 35-39.

4. Лівшиць Г.Б., Кучеренко А.М., Подлєсна С.С., Кравченко С.А., Лівшиць Л.А. Аналіз алельного поліморфізму гена ESR1 серед населення України. Цитология и генетика 2012; 4: 31-39.

5. Наказ № 676 м03 України від 31.12.2004 «Про затвердження клінічних протоколів з акушерської та гінекологічної допомоги».

6. Сметник В.П., Тумилович Л.Г. Неоперативная гинекология: Руководство для врачей. Книга 1. СПб.: СОТИС; 1995. C. 129-138.

7. Joshi G., Pradhan S., Mittal B. Role of the oestrogen receptor (ESR1 Pvull and ESR1 $325 \mathrm{C}>\mathrm{G}$ ) and progesterone receptor (PROGINS) polymorphisms in genetic susceptibility to migraine in a North Indian population. Cephalalgia 2010; 30 (3): 311-20.

8. Miller A., Vo H., Huo L., Roca C., Schmidt P.J., Rubinow D.R. Estrogen receptor alpha (ESR-1) associations with psychological traits in women with PMDD and controls. J Psychiatr Res. 2010; 44 (12): 788-94

9. Schürks M., Rist P.M., Kurth T. Sex hormone receptor gene polymorphisms and migraine: a systematic review and meta-analysis. Cephalalgia. 2010; 30(11): 1306-28.

10. Sundermann E.E., Maki P.M., Bishop J.R. A review of estrogen receptor alpha gene (ESR1) polymorphisms, mood, and cognition. Menopause 2010; 17(4): 874-86

11. Wang W., Li Y., Maitituoheti M., Yang R., Wu Z., Wang T. et al. Association of an oestrogen receptor gene polymorphism in Chinese Han women with endometriosis and endometriosisrelated infertility. Reprod Biomed Online 2013; 26 (1): 93-8.

12. WooH.Y., Kim K.H., LimS.W. Estrogen receptor 1, glutathione S-transferase P1, glutathione S-transferase M1, and glutathione S-transferase T1 genes with dysmenorrhea in Korean female adolescents. Korean J Lab Med 2010; 30 (1):76-83. 